\title{
Internal carotid artery dissection in a patient with Ehlers-Danlos syndrome type IV: diagnosis and management
}

\author{
Dissecção da artéria carótida interna em paciente com síndrome de \\ Ehlers-Danlos tipo IV: diagnóstico e manejo
}

Michel Nasser', Murilo Bucci Vega', Luca Giovani Antonio Pivetta', Ana Izabel Nasser², Débora Gusmão Melo'

\begin{abstract}
Ehlers-Danlos syndrome (EDS) type IV, also known as vascular EDS, is an inherited connective tissue disorder with an estimated prevalence of 1/100,000 to 1/250,000. In EDS type IV, vascular complications may affect all anatomical areas, with a preference for large- and medium-sized arteries. Dissections of the vertebral and carotid arteries in their extra- and intra-cranial segments are typical. The authors report the case of a patient with EDS type IV for whom the diagnosis was established based on clinical signs and who developed internal carotid artery dissection at the age of 44 years. In the absence of a specific treatment for EDS type IV, medical interventions should focus on symptomatic relief, prophylactic measures, and genetic counseling. Invasive imaging techniques are contraindicated, and a conservative approach to vascular complications is usually recommended.
\end{abstract}

Keywords: carotid artery; internal; dissection; Ehlers-Danlos syndrome; diagnosis; disease management.

\begin{abstract}
Resumo
A síndrome de Ehlers-Danlos (EDS) tipo IV, também conhecida como EDS tipo vascular, é uma doença genética do tecido conjuntivo com prevalência estimada entre 1/100.000 e 1/250.000. Na EDS tipo IV, as complicações vasculares podem afetar todas as áreas anatômicas, com comprometimento preferencial de artérias de médio e grande diâmetros. Dissecções das artérias vertebrais e carótidas em seus segmentos intra e extracranianos são típicas. Os autores relatam o caso de uma paciente com EDS tipo IV na qual o diagnóstico sindrômico foi realizado com base nos achados clínicos e que desenvolveu dissecção da artéria carótida interna aos 44 anos. Na ausência de um tratamento específico para EDS tipo IV, a intervenção médica deve ser voltada para o tratamento sintomático, para medidas profiláticas e para o aconselhamento genético. Técnicas de imagem invasivas são contraindicadas e, geralmente, recomenda-se uma abordagem conservadora ao cuidar das complicações vasculares.
\end{abstract}

Palavras-chave: dissecção da artéria carótida interna; síndrome de Ehlers-Danlos; diagnóstico; manejo da doença. 


\section{INTRODUCTION}

Internal carotid artery (ICA) dissection is a condition that results from the infiltration of blood into the vessel wall. It may affect the subintimal and medial layers and lead to artery stenosis or occlusion, or the sub-adventitial layer, which leads to aneurysm formation. ${ }^{1}$ Dissections, which usually affect the superior cervical segment of the extracranial ICA and the supraclinoid segment of its intracranial portion, are often caused by trauma ${ }^{1}$. Other possible causes include fibromuscular dysplasia, fibroelastic changes of the intima, cystic fibrosis of the media and connective tissue diseases, such as the Ehlers-Danlos syndrome ${ }^{1 .}$

The Ehlers-Danlos syndrome (EDS) comprises a heterogeneous set of at least 11 syndromes with specific clinical and genetic characteristics resulting from defects in the synthesis or the structure of several types of collagen ${ }^{2}$. The vascular form of the disease is called EDS type IV, which is an inherited dominant autosomal disorder caused by mutations in gene COL3A1, located in 2q32.2, which encodes the pro-alpha 1 chain (III) of the fibrillar collagen type $\mathrm{III}^{3-5}$. The estimated prevalence of EDS type IV is about $1: 100,000$ to $1: 250,000$ in the general population, and there is no ethnic or sex predilections $^{3,4}$.

Clinically, EDS type IV is characterized by important vascular involvement and a mean life expectancy of 48 years ${ }^{4}$. Vascular complications may affect all anatomic areas, with a preference for large- and medium-sized arteries, and dissections of vertebral and carotid arteries in intra- and extracranial segments are typical events.

EDS type IV is very rare and physicians are not familiar with it. Therefore, the diagnosis is usually made after a catastrophic vascular complication or during autopsy ${ }^{4}$. This report describes a case of EDS type IV in a patient whose most obvious clinical sign was hemiplegia due to spontaneous dissection of the internal carotid artery. The authors also discuss the diagnosis and management of this syndrome in this specific case.

\section{CASE REPORT}

A white, married, 44 years old, woman with no history of pregnacy was seen in the emergency department presenting with dysarthria, hemiplegia and hemiparesia of sudden onset in the upper and lower right extremities. Based on symptoms and imaging studies, a diagnosis of ischemic stroke (IS) was made, and she was treated conservatively in an intensive care unit for one week. After that time, she was discharged and started clinical follow-up with a vascular surgeon, who suspected a connective tissue congenital disease and referred the patient to a geneticist, who established the clinical diagnosis of EDS type IV.

Her family history was relevant, as her brother had a brain aneurysm diagnosed at 17 years, a maternal aunt had an ischemic stroke at 40-45 years, and her maternal grandmother died suddenly due to cardiac arrest at the age of 36 years. Her medical history included umbilical hernia surgery at 21 years of age, resection of uterine leiomyomata at 35 years of age, and operation of varicose veins in the lower limbs at 37 years.

Physical examination revealed a slender profile, thin facial features with deep-set eyes, thin lips, delicate and translucent skin, paucity of subcutaneous tissue, discrete signs of ageing (acrogeria) (Figure 1), loose ligaments in the hands, elbows and knees, negative Steinberg thumb sign and positive WalkerMurdoch wrist sign. Anthropometric data showed that her height was $176.5 \mathrm{~cm}$ (90th-97th percentile), arm span, $173.5 \mathrm{~cm}$ (arm span/height: 0.98), weight, $63 \mathrm{~kg}(50-75 \mathrm{p})$ and cranial circumference, $54.5 \mathrm{~cm}$ (50th-75 the percentile).

Color Doppler ultrasound showed a thin band a two-phase turbulent flow in left ICA, with hypoechoic material in its lumen filling more than $60 \%$ of the diameter of the segment evaluated (Figure 2).

She underwent magnetic resonance angiography (MRA) to examine cervical vessels, and results revealed stenosis of about $80 \%$ to $90 \%$ of the proximal segment of the left ICA, about $2.5 \mathrm{~cm}$ above its emergence (Figure 3).

The investigation continued by using other imaging methods and, because the patient was allergic to iodinated contrast, angiography with carbon dioxide was chosen. The scan showed an image compatible

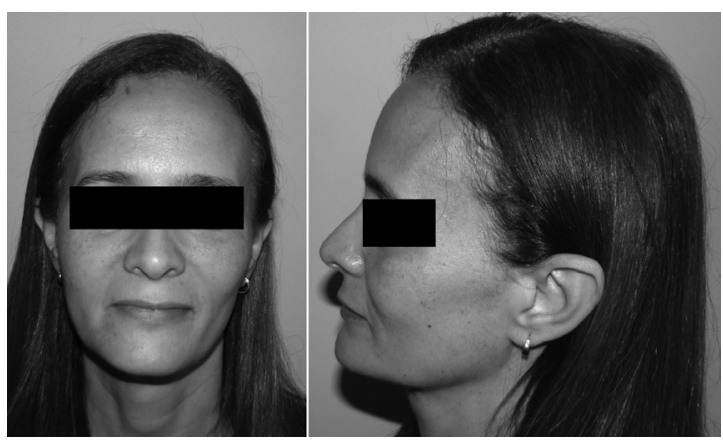

Figure 1. Patient in reported case. Thin facial features, thin lips, thin skin and paucity of subcutaneous tissue. 


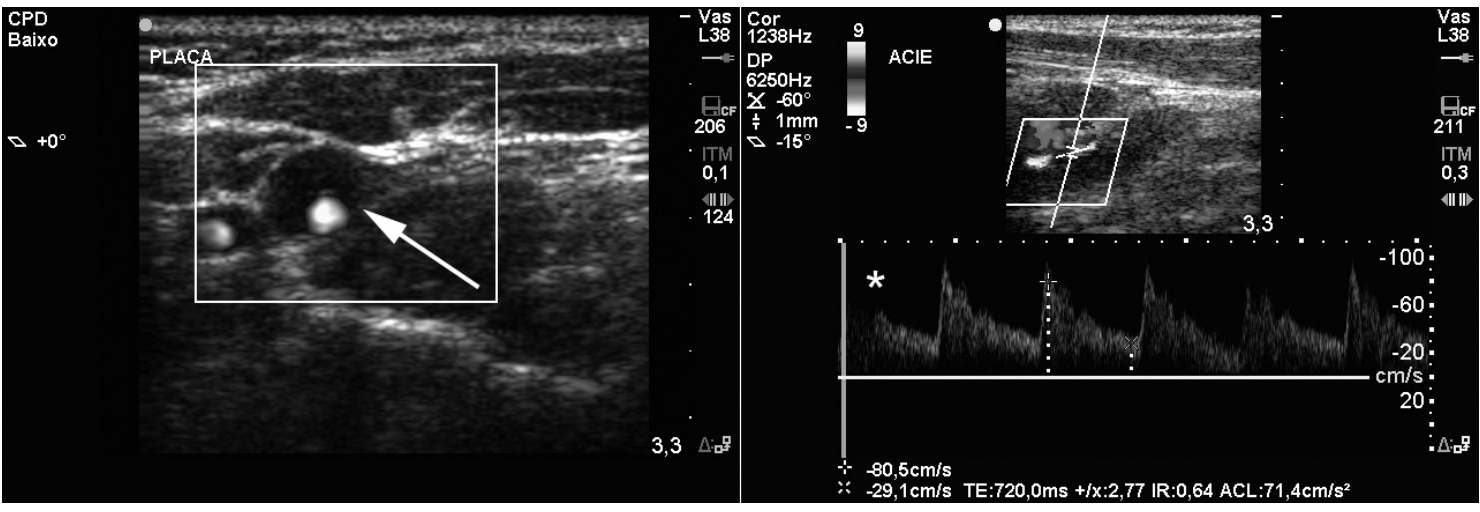

Figure 2. Doppler ultrasound scan of carotid artery shows hyperechoic material in left ICA lumen (arrow) and narrow area of two-phase, turbulent flow $\left({ }^{*}\right)$.

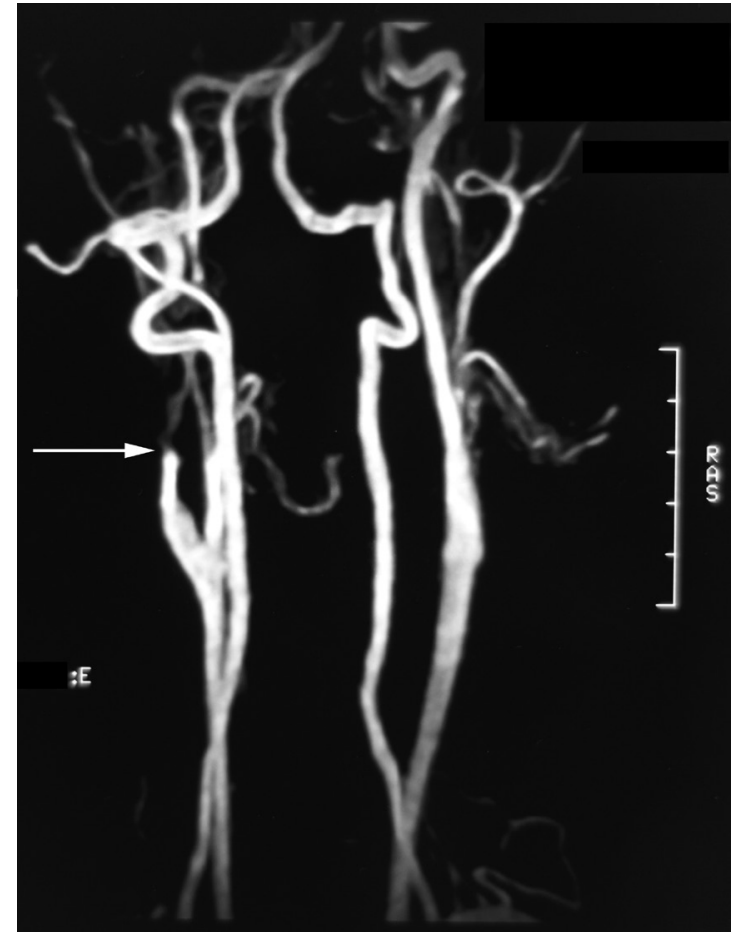

Figure 3. MRA of cervical vessels shows narrowing of left ICA segment (arrow).

with an intimal flap in the bulbar portion of the left ICA and narrowing up to about the beginning of the petrous segment, findings associated with acute dissection of the left ICA. In addition, there was a saccular dilatation measuring $0.5 \mathrm{~cm}$ of diameter at about $1.5 \mathrm{~cm}$ from the carotid bifurcation, which was suggestive of a pseudoaneurysm (Figure 4).

She has been followed up by a vascular surgeon in the outpatient service, and has been taking antiplatelet agents (clopidogrel, $75 \mathrm{mg} /$ day). At every 6 months, she undergoes ultrasound

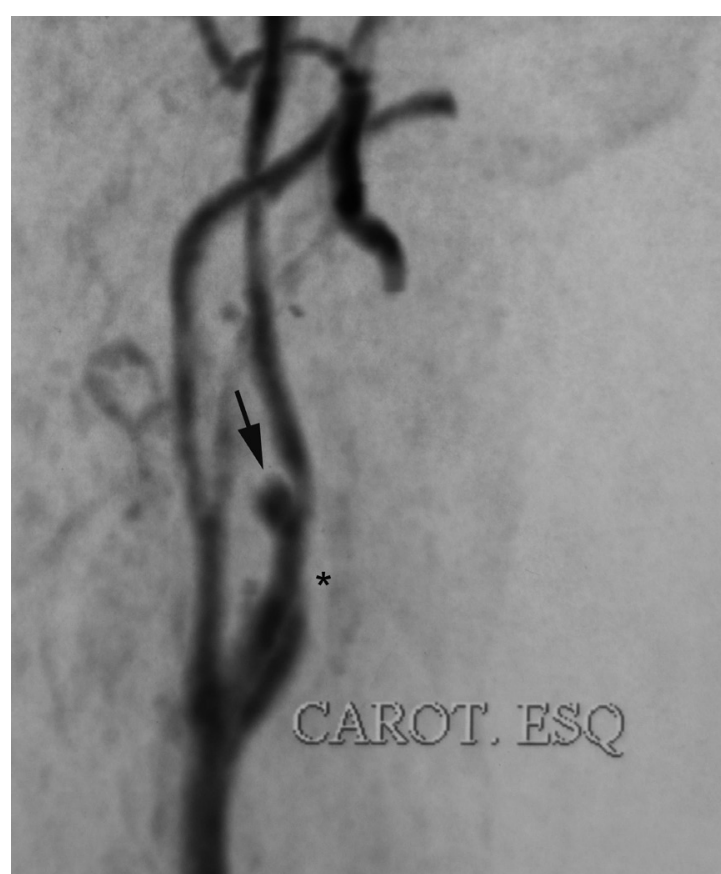

Figure 4. Carbon dioxide angiogram shown narrowing of left ICA segment starting in bulbar region $\left(^{*}\right)$ and pseudoaneurysm (arrow).

scanning because of her bicuspid aortic valve; abdominal ultrasound to evaluate the abdominal aorta; and ultrasound scanning of the carotid arteries. She also undergoes treatment with a speech therapists and a physiotherapist due to the sequelae of the ischemic stroke. She was seen by a geneticist, underwent non-directive genetic counseling, and received information about prophylactic measures, risks associated with pregnancy and the clinical and inherited characteristics of EDS type IV. 


\section{DISCUSSION}

The clinical diagnosis of EDS type IV is usually made according to the criteria defined in 1997 during the Villefranche Conference ${ }^{6-9}$, shown in Table 1. The presence of two or more major diagnostic criteria suggests the diagnosis, and biochemical or molecular genetic tests should be performed for confirmation. ${ }^{2}$ Biochemical tests evaluate collagen type III by means of electrophoresis of proteins in fibroblasts cultured in material collected for skin biopsy ${ }^{9}$. Molecular tests evaluate DNA directly, and include the complete sequencing of the COL $3 A 1$ gene (reference criterion for laboratory investigation because it detects $95 \%$ of the mutations that cause the disease ${ }^{4}$ ) and the analysis of deletions and insertions more frequently associated with the disease using different techniques, such as polymerase chain reaction (PCR) and multiplex ligation-dependent probe amplification (MLPA) ${ }^{10}$.

In clinical practice, it is very difficult to perform genetic tests to confirm EDS type IV. Currently, biochemical and molecular tests to identify EDS type IV are performed by only 18 laboratories registered in GeneTests, an American site sponsored by the National Center for Biotechnology Information (NCBI), an association of international laboratories that conduct genetic tests approved by the Food and Drug Administration (FDA $)^{10 .}$ In Brazil, despite the National Comprehensive Health Care Policy for Clinical Genetics of the Brazilian Unified Health System, most patients with genetic diseases do not have access to medical geneticists or the necessary genetic testing ${ }^{11}$. The patient in this case report had a clinical diagnosis because she met three major

Table 1. Diagnostic criteria of EDS type IV (adapted from BEIGHTON et al., 1998)²

\begin{tabular}{l}
\hline Major diagnostic criteria \\
\hline Thin and translucent skin \\
Arterial, intestinal or uterine fragility or rupture \\
Extensive bruising \\
Characteristic facial appearance, including thin and delicate \\
nose, deeply-set eyes, thin lips and hollow cheeks with paucity \\
of adipose tissue \\
\hline Minor diagnostic criteria \\
Acrogeria \\
Hypermobility of small joints \\
Muscle and/or tendon rupture \\
Early-onset varicose veins \\
Talipes equinovarus (clubfoot) \\
Arteriovenous, carotid-cavernous sinus fistula \\
Pneumothorax/pneumohemothorax \\
Gingival retraction \\
Positive family history, sudden death of (a) close relative(s)
\end{tabular}

criteria (thin and translucent skin, characteristic facial features and fragility of arterial walls) and at least three minor criteria (joint hypermobility, early onset of varicose veins and family history of sudden death), but she has not had access to specific genetic tests to this date. An American study analyzed a series of 31 cases of EDS type IV and found that 24 patients $(77.3 \%)$ underwent biochemical tests, $11(35.5 \%)$ had molecular tests and $7(22.7 \%)$ had a clinical diagnosis ${ }^{12}$

The diagnosis of EDS type IV may be suggested by any ischemic stroke in a young individual ${ }^{13,14}$, as the syndrome is usually suspected only after vascular complications ${ }^{7,9}$. Intracranial hemorrhages affect $4 \%$ of the patients with EDS type IV, and half of these cases are caused by the rupture of previously detected intracranial aneurysms ${ }^{15}$. In a series of 31 patients with EDS type IV, $25 \%$ had complications that affected the carotid arteries, and 2 patients had dissections ${ }^{12}$. ICA dissections are clinically characterized by a triad of headache (frontal, orbital or peri-orbital), neck pain and partial ipsilateral Horner syndrome (ptosis and myosis). However, carotid dissection is unilateral in most cases, and the patient rarely presents with the classical triad ${ }^{1}$. About $50 \%$ to $95 \%$ of the patients with ICA dissection are estimated to have a subsequent stroke. A Brazilian study with 48 patients conducted from 1997 to 2003 found that the mean time interval from symptom onset to ischemic focal deficit was four to five days ${ }^{16}$.

In cases of ICA dissection, the diagnosis of EDS type IV is important for the vascular diagnosis and should define treatment. Defects in collagen type III synthesis make patients highly susceptible to artery or vein ruptures that are difficult to repair surgically ${ }^{9,12}$. Therefore, invasive imaging studies ${ }^{3,17}$, such as intra-arterial digital subtraction angiography, the reference standard in the investigation of ICA dissection ${ }^{1,18}$, are contraindicated. Several non-invasive vascular imaging techniques may be helpful in establishing a diagnosis: extracranial and transcranial Doppler ultrasound and color-coded duplex ultrasound; computed tomography (CT); magnetic resonance (MR); and magnetic resonance angiography (MRA). Ultrasound studies have a joint sensitivity of $95 \%$, but are limited for the visualization of distal ICA dissections. MRI and MRA provide better visualization of morphology and blood flow in the carotid arteries, but also have disadvantages, such as a tendency to overestimate the degree of stenosis, the production of artifacts due to swallowing or patient movements, and a lower capacity to detect acute hematomas ${ }^{1,16,18}$. When 
combined, non-invasive vascular imaging studies are the best option for patients with EDS type IV ${ }^{3,12,17}$.

In the case reported here, Doppler ultrasound, MRA and carbon dioxide angiography confirmed ICA dissection, and the patient did not have to undergo surgery. Studies in the literature suggest that the risk of weakening arterial walls during surgery is high because of the fragility of vessels in patients with EDS type IV. Standard vascular sutures usually lead to tearing, and the best choices for these patients are arterial ligatures, as long as they do not compromise the blood supply to the organ, or a carotid bypass. Other precautions include the delicate and atraumatic handling of the artery and the use of soft, coated clamps or occlusion balloons instead of standard clamps ${ }^{1,3,9,12}$. However, no conclusive data about the use of stents are available ${ }^{12}$.

In general, patients that had spontaneous ICA dissection should receive prolonged anticoagulation treatment with heparin and warfarin for 3 to 6 months to prevent artery-to-artery embolism, and the treatment should be discontinued when there is full arterial recanalization ${ }^{1,16}$. In a small percentage of cases, recanalization is not achieved after six months, and surgical revascularization may be used ${ }^{1}$. In patients with EDS type IV, treatment should be conservative whenever possible, and surgery should be limited to unavoidable, life-threatening situations $\mathrm{s}^{3,12,17}$. Minimally symptomatic aneurysms should not be operated on electively unless there are signs of rapid expansion and imminent rupture ${ }^{12}$. Patients with aneurysms treated conservatively should be examined at intervals of 3 to 6 months using non-invasive vascular imaging techniques ${ }^{12}$. When there is no aneurysm, the usefulness of routine vascular screening is controversial ${ }^{3}$, but some authors recommend a yearly follow-up visit for a careful physical examination, echocardiogram, carotid and abdominal ultrasound, as well as chest and abdominal $\mathrm{CT}$ and MRI in case there are incidental findings ${ }^{3,12}$.

Several studies have compared anticoagulants and antiplatelet agents for cases of cervical artery dissections, and both medications seem to have similar results ${ }^{19}$. Additionally, a recent multicenter study with patients with EDS type IV showed that the use of celiprolol, a $\beta(1)$-adrenoceptor antagonist with a $\beta(2)$-adrenoceptor agonist action, reduces the incidence of dissection or arterial ruptures threefold ${ }^{20}$. Although celiprolol was approved for use in Brazil in $1996,{ }^{21}$ it is not easily found in the market in this country ${ }^{22}$, and it is usually imported, which complicates its use by patients.
Specifically, the clinical management of patients with EDS type IV should include the adoption of general prophylactic measures: the elimination of intense physical activity, violent sports or diving; the awareness of the vascular risks of pregnancy (maternal death is about 12\%); and, ideally, the use of contraception ${ }^{3}$. As EDS type IV is an autosomal dominant trait, patients should receive genetic counseling and be aware that the risk of recurrence for their offspring is $50 \%{ }^{3-5}$.

\section{CONCLUSION}

Vascular surgeons should keep in mind the possibility of EDS type IV and its severe vascular complications. Patients with this disease require special care before, during and after operation.

\section{ACKNOWLEDGEMENTS}

The authors thank the patient for the permission to report on her case.

\section{REFERENCES}

1. Chaves C. Dissecção da artéria carótida. Rev Bras Cardiol Invas 2008;16(3): 353-61. http://dx.doi.org/10.1590/ S2179-83972008000300018

2. Beighton P, De Paepe A, Steinmann B, Tsipouras P, Wenstrup RJ. Ehlers-Danlos syndromes: revised nosology, Villefranche, 1997. Ehlers-Danlos National Foundation (USA) and Ehlers-Danlos Support Group (UK). Am J Med Genet. 1998;77(1):31-7. http://dx.doi.org/10.1002/ (SICI)1096-8628(19980428)77:1<31::AID-AJMG8>3.0.CO;2-O

3. Germain DP. Ehlers-Danlos syndrome type IV. Orphanet J Rare Dis. 2007;2:32. PMid:17640391 PMCid:1971255. http://dx.doi. org/10.1186/1750-1172-2-32

4. Pepin MG, Byers PH. Ehlers-Danlos Syndrome Type IV. In: Pagon RA, Bird TD, Dolan CR, et al., editors. GeneReviews ${ }^{\mathrm{TM}}$ [Internet]. Seattle: University of Washington; 1993. [atualizado 2011 maio 3; citado 2013 fev. 8]. http://www.ncbi.nlm.nih.gov/books/ NBK1494/.

5. Online Mendelian Inheritance in Man - OMIM ${ }^{\circledR}$. [Internet]. Johns Hopkins University, Baltimore, MD. MIM Number \#130050. [atualizado 2012 out 2; citado 2013 fev. 8]. http://omim.org/ entry/130050.

6. Dwivedi AM, Hamdallah O, Morris ME, Yancey AE, Ross CB. Varying presentations in patients with symptomatic type IV vascular EhlersDanlos syndrome. Vasc Endovascular Surg. 2012;46(2):163-66 PMid:22308214. http://dx.doi.org/10.1177/1538574411433298

7. Nakamura M, Yajima J, Oikawa Y, et al. Vascular Ehlers-Danlos syndrome - all three coronary artery spontaneous dissections. J Cardiol. 2009; 53: 458-62. PMid:19477391. http://dx.doi. org/10.1016/j.jjcc.2008.09.007

8. Hampole CV, Philip F, Shafii A, et al. Spontaneous Coronary Artery Dissection in Ehlers-Danlos syndrome. Ann Thorac Surg. 2011;92:1883-84. PMid:22051286. http://dx.doi. org/10.1016/j.athoracsur.2011.03.136 
9. Imamura $\mathrm{A}$, Nakamoto $\mathrm{H}$, Inoue $\mathrm{T}$, et al. Ruptured dissecting aneurism in bilateral iliac arteries caused by Ehlers-Danlos syndrome type IV: report of a case. Surg Today. 2001;31:85-9. PMid:11213052. http://dx.doi.org/10.1007/s005950170228

10. GeneTests Medical Genetics Information Resource [Internet]. Copyright, University of Washington, Seattle. 1993-2013. [citado 2013 fev. 8]. http://www.ncbi.nlm.nih.gov/sites/ GeneTests/lab/clinical_disease_id/2067?db=genetests.

11. Melo DG, Sequeiros J. The challenges of incorporating genetic testing in the unified national health system in Brazil. Genet Test Mol Biomarkers. 2012;16(7):651-5. PMid:22533694. http://dx.doi. org/10.1089/gtmb.2011.0286

12. Oderich GS, Panneton JM, Bower TC, et al. The spectrum, management and clinical outcome of Ehlers-Danlos syndrome type IV: A 30-year experience. J Vasc Surg. 2005;42:98-106. PMid:16012458. http://dx.doi.org/10.1016/j.jvs.2005.03.053

13. Germain DP, Herrera-Guzman Y. Vascular Ehlers-Danlos syndrome. Ann Genet. 2004;47(1):1-9. PMid:15127738. http:// dx.doi.org/10.1016/j.anngen.2003.07.002

14. Germain DP. The vascular Ehlers-Danlos syndrome. Curr Treat Options Cardiovasc Med. 2006;8(2):121-27. PMid:16533486. http://dx.doi.org/10.1007/s11936-006-0004-z

15. Schievink WI. Cerebrovascular involvement in Ehlers-Danlos syndrome. Curr Treat Options Cardiovasc Med. 2004;6(3):231-36. PMid:15096315. http://dx.doi.org/10.1007/s11936-996-0018-6

16. Campos CR, Evaristo EF, Yamamoto FJ, Puglia P Jr, Lucato LT, Scaff M. Dissecção espontânea cervical carotídea e vertebral. Arq Neuropsiquiatr. 2004;62(2-B):492-98. PMid:15273850. http:// dx.doi.org/10.1590/S0004-282X2004000300021

17. De Paepe A, Malfait F. The Ehlers-Danlos syndrome, a disorder with many faces. Clin Genet 2012;82:1-11. PMid:22353005. http:// dx.doi.org/10.1111/j.1399-0004.2012.01858.x

18. Pieri A, Spitz M, Valiente RA, Avelar WM, Silva GS, Massaro AR. Dissecção espontânea das artérias carótidas e vertebrais em uma população multiétnica. Arq Neuropsiquiatr. 2007;65(4A):1050-55. PMid:18094876. http://dx.doi.org/10.1590/ S0004-282X2007000600029
19. Kennedy F, Lanfranconi S, Hicks C, et al. Antiplatelets vs anticoagulation for dissection. Neurology. 2012;79:68689. PMid:22855862. http://dx.doi.org/10.1212/ WNL.0b013e318264e36b

20. Ong KT, Perdu J, De Backer J, et al. Effect of celiprolol on prevention of cardiovascular events in vascular Ehlers-Danlos syndrome: a prospective randomised, open, blinded-endpoints trial. Lancet. 2010; 376(9751):1476-84. http://dx.doi.org/10.1016/ S0140-6736(10)60960-9

21. Brasil. Ministério da Saúde. Portaria no. 1.179, de 17 de junho de 1996. [Internet]. [citado 2013 abr. 4]. http://www.pharmanet. com.br/legisla/port1179.htm

22. Sociedade Brasileira de Cardiologia, Sociedade Brasileira de Hipertensão, Sociedade Brasileira de Nefrologia. Tratamento Medicamentoso. VI Diretrizes Brasileiras de Hipertensão. Arq Bras. Cardiol. 2010;95(Supl.1):1-51.

Correspondence Michel Nasser DMed

Rod. Washington Luís, SP-310, Km 235, Campus da UFSCar CEP 13565-905 - São Carlos, SP, Brazil E-mail:nasser@ufscar.br; michelnasser@uol.com.br

Author information MN and DGM are adjunct professor at the Department of Medicine of Universidade Federal de São Carlos (UFSCar).

MBV and LGAP are graduate students in Medicine, Department of Medicine, Universidade Federal de São Carlos (UFSCar)

AIN is a medical student at Universidade Federal de São Paulo (UNIFESP)

Author's contributions Conception and design: $M N$, DGM Analysis and interpretation: MN, MBV, LGAP, AIN, DGM Data collection: MBV, LGAP, AIN Writing the article: MN, MBV, LGAP, AIN, DGM Critical revision of the article: $M N, D G M$ Final approval of the article*: MN, MBV, LGAP, AIN, DGM Statistical analysis: N/A Overall responsibility: $M N$

*All authors should have read and approved of the final version of the article submitted to I Vasc Bras. 